\title{
From the Editor: Revisiting Family Therapy and Family Medicine
}

\author{
Dorothy S. Becvar
}

Published online: 30 April 2011

(c) Springer Science+Business Media, LLC 2011

In 1969, family medicine was designated as a separate area of expertise in response to increasing specialization and reductionism within the medical field (Becvar and Becvar 2009). However, although they shared common concerns and ideas, it wasn't until the early 1980s that formal working relationships between family therapists and practitioners of family medicine were established. Most notable in this regard were the creation by Don Bloch in 1982 of the journal Family Systems Medicine (now called Families, Systems and Health), and the publication in 1983 of Family Therapy and Family Medicine: Toward the Primary Care of Families by William Doherty and Macaran Baird. Then, in the spring of 1990, the American Association for Marriage and Family Therapy (AAMFT) and the Society of Teachers of Family Medicine (STFM) created a joint task force whose goal was to identify common practices and areas for partnering around the education and training of family therapists and family physicians (Tilley 1990). Nichols and Schwartz (2004) noted the success of such efforts in the subsequent emergence of a distinct collaborative family health care paradigm, as indicated by many publications and an annual conference devoted to this topic.

The basic commonality between these two professions is their holistic or systemic orientation. Thus both family therapists and family physicians recognize the importance of considering context, including biological, psychological, family, and social systems (Henao 1985), when attempting to understand how problems emerge, are maintained, and may be solved. Within the medical field, George Engel $(1977,1992)$ was a strong proponent of a biopsychosocial model. Similarly, Wynne et al. (1992) urged family therapists to overcome their ambivalence about the idea of illness, and to "conceptualize and differentiate the varieties of illness/distress from one another in order to clarify, strengthen, and broaden the scope of family therapy, theory, and clinical practice" (p. 16).

In the years that have followed such admonitions, a great deal of attention has been given to the creation of practice models that involve collaboration between professionals from both fields. What is more, behavioral scientists, who often are family therapists, have become important members of the faculties of family medicine training programs.

D. S. Becvar $(\bowtie)$

School of Social Work, Saint Louis University, St. Louis, MO, USA

e-mail: becvards@slu.edu 
In addition, there has been increasing recognition of the mind/body connection. In the medical field this is perhaps best exemplified by the emergence of complementary and alternative medicine as well as integrative medicine. And within the family therapy field, increasing numbers of articles on mindfulness have found their way into the professional literature. And certainly much research in both fields has focused on the connections between physical and mental/emotional health and well-being.

Thus it has been my pleasure to work with Maria Cristina Canavarro and Frank Dattilio in putting together this special issue on Family Therapy and Medical Issues. Our brief partnership and the work described are certainly consistent with the now long-standing collaborative efforts between family therapists and family physicians. On the one hand, the articles included provide important information relative to current issues faced by professionals in both fields. On the other hand, given that all of the research was conducted in Portugal, we also continue an important emphasis on the international nature of this journal. More about the specific contents of this issue can be found in the introduction provided by the guest editors.

\section{References}

Becvar, D. S., \& Becvar, R. J. (2009). Family therapy: A systemic integration (7th ed. ed.). Boston: Allyn \& Bacon.

Doherty, W. J., \& Baird, M. A. (1983). Family therapy and family medicine: Toward the primary care of families. New York: Guilford.

Engel, G. (1977). The need for a new medical model: A challenge for biomedicine. Science, 196, 129-136.

Engel, G. (1992). How much longer must medicine's science be bound by a seventeenth century world view? Family Systems Medicine, 10(3), 333-346.

Henao, S. (1985). A systems approach to family medicine. In s. Henao \& N. P. Grose (Eds.), Principles of family systems in family medicine (pp. 24-40). New York: Bruner/Mazel.

Nichols, M. P., \& Schwartz, R. C. (2004). Family therapy: Concepts and methods (6th ed. ed.). Boston: Allyn \& Bacon.

Tilley, K. (1990). Family medicine-family therapy joint task force established Family Therapy News p. 1.

Wynne, L. C., Shields, C., \& Sirkin, M. (1992). Illness, family theory, and family therapy: I. Conceptual issues. Family Process, 31, 3-18. 